\title{
An Evaluation of e-Health Literacy in University Students: The Example of Yozgat Bozok University
}

\author{
Şemsinnur Göçer ${ }^{1}$ (D) , Elçin Balcı² (DD , Nursel Üstündağ Öcal ${ }^{3}$ (iD
}

'Sarikaya Physiotherapy and Rehabilitation, Yozgat / Turkey

${ }^{2}$ Erciyes University, Faculty of Medicine, Department of Public Health, Kayseri / Turkey

${ }^{3}$ Yozgat Bozok University Health Services Vocational School, Yozgat / Turkey

Şemsinnur GÖÇER, Dr. Öğr. Üyesi Elçin BALCl, Prof. Dr. Nursel ÜSTÜNDAĞ ÖCAL, Dr. Öğr. Üyesi

This study was presented as a poster at the 3rd International 21st National Public Health Congress held in Antalya between 26-30 November 2019.

Correspondence: Nursel Üstündağ Öcal Yozgat Bozok University Health Services Vocational School, Istanbul / Turkey Phone: +903542421034

E-mail: nursel.ustundagocal@yobu.edu.tr

\begin{abstract}
Aim: It is stated that social media sites, which has been started to be used widely also in the field of health, are used as a potential resource for health information. In our work; It is aimed to determine the level of e-health literacy level among university students.

Methods: This research is a descriptive study. The study was carried out on the students of Yozgat Bozok University, Faculty of Education. This research was conducted in May and June 2019. Ethical approval for the research was obtained from Erciyes University Clinical Research Ethics Committee. The research was carried out with the necessary permission from Yozgat Bozok University. The research was completed with 310 people who are willing to participate in the study and have no communication problems. Questions containing socio-demographic information and e-health literacy scale were given to collect data from students.

Results: The average age of the group participating in the study was $21.0 \pm 0.1$ years, $69.0 \%$ of the participants were women. $69.7 \%$ of the participants stated that they had problems in complying with the medical advice or suggestions and that they received the necessary support from the physicians. $57.7 \%$ of the participants stated that they could understand that they did not have any problems with the informed consent forms. The total score average of the students on the e-health literacy scale was $28.4 \pm 0.3$
\end{abstract}

Conclusion: In our study, it was determined that the e health literacy score averages of the students were above the middle level.

Keywords: Health literacy, internet, social media, students

\section{Üniversite Öğrencilerinde e-Sağlık Okuryazarlığının Değerlendirilmesi}

ÖZET

Amaç: Sağlık alanında da yaygın olarak kullanılmaya başlayan sosyal medya sitelerinin online sağlık bilgileri için de potansiyel bir kaynak olarak kullanıldığı belirtilmektedir. Yaptığımız çalışmada; e-sağlık okuryazarlık düzeyinin üniversite öğrencilerindeki düzeyinin belirlenmesi amaçlanmıştır.

Gereç ve Yöntemler: Bu araştırma Tanımlayııı tipte bir araştırmadır. Çalışma Yozgat Bozok Üniversitesinde Eğitim Fakültesinde öğrenim gören öğrenciler üzerinde gerçekleştirilmiştir. 2019 Mayıs ve Haziran aylarında bu araştırma gerçekleştirilmiştir. Araştırma için etik onay Erciyes Üniversitesi Klinik Araştırmalar Etik Kurulu'ndan alınmıştır. Yozgat Bozok Üniversitesi'nden gerekli izin alınarak araştırma gerçekleştirilmiş̧ir. Araştırma çalışmaya katılıakta istekli olan ve iletişim sorunu bulunmayan 310 kişi ile tamamlanmıştı. Öğrencilerden veri toplamak için sosyo-demografik bilgileri içeren anket soruları ve e-sağlık okuryazarlığı ölçeği kullanıımıştır.

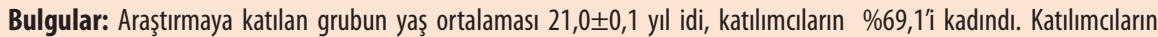
$\% 69,7$ 'si verilen tıbbi tavsiye veya önerilere uyma konusunda problem yaşadıklarını gerekli desteği hekimlerden aldıklarını bildirmişlerdir. Katılımcıların \%57,7'si aydınlatılımıs onam formlarında sorun yaşamadıklarını anlayabildiğini bildirmişlerdir. Öğrencilerin \%57,4'ü internetin sağlıkla ilgili kararlar almada ve sağlık konuları ile ilgili kaynaklara ulaşmada katkı sağladığını bildirmişlerdir. Öğrencilerin, e-sağık okuryazarlığı ölçeği toplam puan ortalaması ise $28,4 \pm 0,3$ idi.

Sonuç: Araştırmamızda, öğrencilerin e-sağlık okuryazarlığı puan ortalamalarının orta düzeyin üzerinde olduğu belirlenmiş̧tir.

Anahtar Kelimeler: Sağlık okuryazarlığı, internet, sosyal medya, öğrenciler

$\begin{array}{ll}\text { Received } & : 31 \text { January } 2021 \\ \text { Accepted } & : \text { : } 14 \text { April } 2021\end{array}$


$\mathbf{T}$ oday, it is one of the most frequently used sources to access internet information sources. Health is one of these issues, and about half of the people trying to access information about health issues on the Internet are; They stated that it has an important effect on understanding health problems and communicating with physicians $(1,2)$.

Interactive web environments, which are considered as indispensable means of information in recent years and called new media, are important in terms of health literacy, apart from tools such as television, newspapers and radio classified as traditional media.

In addition, social networks enable the spread of health information to be shared online, building masses, spreading the message to large audiences, and changing interactions with other people and human relations through rapid announcement and impact (3) It is stated that they are widely used in the health field and recently, social media sites are becoming a potential source for online health information (4).

Considering e-health literacy as a concept, it is a multifaceted concept that is in the middle between health literacy and information technology literacy dimensions. (5).

Although eHealth literacy is associated with health or health literacy, it requires the ability to learn about and use electronic resources. (6).

Pourravazi et al. (7) Defining e-health literacy as contributing to the improvement of healthcare by using information and communication Technologies, Norman and Skinner (8) define this as the process of searching, collecting, interpreting, and evaluating health-related issues from electronic sources such as information communication technologies. (8).

"E-health literacy", which is developed for the literacy level of users, especially young people, who scan information in the field of health, is an important resource in this sense.

When health-related searches are made over the Internet, many uncontrolled misinformation can affect health, but may also cause individuals to be misled.

For this reason, it is important for individuals to have knowledge and awareness at the point of e-health literacy.
In this study; nowadays, access to the internet is getting easier with the effect of advanced technology, and it is aimed to determine the information search, find and use cases with the e-health literacy scale to get information about any health problem from internet resources or to solve this problem in university students with a high rate of internet usage.

\section{Materials and Methods}

Descriptive type research, in Yozgat Bozok University Faculty of Education

It was held in May-June 2019. In the study, it was planned to do not go to the sample account, but with 400 students who are studying in the last year of the faculty.

Since 30 students did not agree to participate in the study and 60 students could not be reached, the study was completed with 310 students. The rate of participation in the research is $77.5 \%$.

A socio-demographic questionnaire consisting of demographic questions such as age, gender and social security and e-health literacy scale were used as data collection tools.

The e-health literacy scale, which was developed by Norman and Skinner (8) in 2006 and whose Turkish validity and reliability study was conducted by Tamer Gencer (9) in 2017, includes items related to internet usage and measuring internet attitude. There are a total of 8 questions in the scale. Scale items; It was arranged as " $1=$ strongly disagree, 2 = disagree, $3=$ undecided, $4=$ agree, $5=$ absolutely agree" with 5-point likert type scaling method. It is known that the lowest score that can be obtained from the scale is 8 and the highest score is 40 . High scores from the scale indicate a high level of e-health literacy. (9).

\section{Ethical approval}

For the study, ethical approval from Erciyes University Clinical Research Ethics Committee with the number 2019/252 and dated 03.04.2019 and institutional permission from Yozgat Bozok University were obtained.

\section{Data Analysis}

Normality analysis was performed using the Shapiro Wilk test. Since the data showed normal distribution, the T test was used to compare pairs of groups, and One way Anova was used to compare three or more groups. 
In statistical analysis, the data obtained from the e-health Literacy Scale were scored according to the instructions of the scale. Number and percentage were used in descriptive data, and One Way Anova t test was used in data related to the scale. $\mathrm{P}<0.05$ values were considered significant.

\section{Results}

Results regarding the descriptive characteristics of the students are given in Table 1. The average age of the study group is $21.0 \pm 0.1$ years, $69.0 \%$ were women. $52.3 \%$ were studying in the department of basic education sciences. $87.4 \%$ had social security, $70.6 \%$ of them were living in a dormitory.

\begin{tabular}{|c|c|c|c|}
\hline \multicolumn{2}{|l|}{ SPECIFICATIONS } & $\mathrm{n}$ & $\%$ \\
\hline \multirow{2}{*}{ Age groups } & $18-24$ & 298 & 96.1 \\
\hline & 25 and above & 12 & 3.9 \\
\hline \multirow{2}{*}{ Gender } & Female & 214 & 69.0 \\
\hline & Male & 96 & 31.0 \\
\hline \multirow{4}{*}{ Department } & Basic educational sciences & 162 & 52.3 \\
\hline & Liberal arts & 129 & 41.6 \\
\hline & Science & 6 & 1.9 \\
\hline & Educational Sciences & 13 & 4.2 \\
\hline \multirow{2}{*}{ Social security } & Yes & 271 & 87.4 \\
\hline & No & 39 & 12.6 \\
\hline \multirow{3}{*}{ Living place } & With the family & 53 & 17.1 \\
\hline & With friend & 38 & 12.3 \\
\hline & Student dormitory & 219 & 70.6 \\
\hline \multirow{3}{*}{ Family type } & Elementary Family & 256 & 82.8 \\
\hline & extended family & 42 & 13.6 \\
\hline & parents separated & 11 & 3.6 \\
\hline \multirow{4}{*}{$\begin{array}{l}\text { Mother } \\
\text { education level }\end{array}$} & illiterate & 28 & 9.0 \\
\hline & literate & 18 & 5.8 \\
\hline & Primary education & 195 & 62.9 \\
\hline & High school and above & 69 & 22.3 \\
\hline \multirow{4}{*}{$\begin{array}{l}\text { Father } \\
\text { education level }\end{array}$} & illiterate & 6 & 1.9 \\
\hline & literate & 3 & 1.0 \\
\hline & Primary education & 201 & 64.8 \\
\hline & High school and above & 100 & 32.3 \\
\hline \multirow{2}{*}{ Illness } & Yes & 44 & 14.2 \\
\hline & No & 266 & 85.8 \\
\hline \multicolumn{2}{|l|}{ Total } & 310 & 100.0 \\
\hline
\end{tabular}

$82.8 \%$ of the students had a nuclear family. According to the results about the mother (62.9\%) and father (64.8\%) education level of the students, the rate of the students at primary education level was higher. $14.2 \%$ of the students stated that they have a disease.

Table 2. Distribution of students' informed consent and

knowledge of the concept of e-health literacy, and their

thoughts on the use of the Internet in relation to health and the usefulness of the Internet in e-health literacy

\begin{tabular}{|c|c|c|c|}
\hline & & $\mathrm{n}$ & $\%$ \\
\hline & Physician & 174 & 56.2 \\
\hline Where do you get the most & Internet, media tools & 121 & 39.0 \\
\hline & TV & 15 & 4.8 \\
\hline Where do you get the most & Physician & 216 & 69.7 \\
\hline information on adherence & TV & 93 & 30.0 \\
\hline recommendations? & Internet, media tools & 1 & 0.3 \\
\hline & Not useful at all & 19 & 6.1 \\
\hline Do you think the internet & Not helpful & 46 & 14.8 \\
\hline is useful in making health- & No idea & 49 & 15,8 \\
\hline related decisions? & Helpful & 178 & 57,4 \\
\hline & Very helpful & 18 & 5,8 \\
\hline & Does not matter & 7 & 2.3 \\
\hline How importar & It does not matter & 42 & 13.5 \\
\hline access health resources on & No idea & 38 & 12,3 \\
\hline & Important & 178 & 57,4 \\
\hline & Very important & 45 & 14.5 \\
\hline & Yes & 65 & 21.0 \\
\hline Do you know about & No & 148 & 47.7 \\
\hline & Partially & 97 & 31.3 \\
\hline Can you understand the & Yes & 179 & 57.7 \\
\hline infor & No & 131 & 42.3 \\
\hline Total & & 310 & 100.0 \\
\hline
\end{tabular}

$56.2 \%$ of the students stated that they received the support from the physician when they had problems with their health-related information, $69.7 \%$ of the medical advice or recommendations. $57.4 \%$ of the students stated that the internet plays an important role in searching and finding health information and is useful in making decisions about health.

It has been determined that the rate of students who have information about e-health literacy is $21 \%$ and $57.7 \%$ of the students can understand the informed consent forms. 
Table 3. Comparison of students' e-health literacy total score average and total scores in terms of some characteristics

\begin{tabular}{|c|c|c|c|}
\hline & Mean \pm SS & $\mathrm{t}$ & $\mathrm{p}$ \\
\hline Age group & & \multirow{3}{*}{0,735} & \multirow{3}{*}{0,463} \\
\hline $18-24$ & $28,4 \pm 5,8$ & & \\
\hline$\geq 25$ & $27,6 \pm 6,8$ & & \\
\hline Gender & & \multirow{3}{*}{$-0,366$} & \multirow{3}{*}{0,714} \\
\hline Female & $28,1 \pm 5,9$ & & \\
\hline Male & $29,0 \pm 5.7$ & & \\
\hline Social security & & \multirow{3}{*}{1,110} & \multirow{3}{*}{0,268} \\
\hline Yes & $28,6 \pm 5,8$ & & \\
\hline No & $26,8 \pm 6,4$ & & \\
\hline \multicolumn{2}{|l|}{ Disease state } & \multirow{3}{*}{$-0,244$} & \multirow{3}{*}{0,807} \\
\hline Yes & $28,0 \pm 5,7$ & & \\
\hline No & $28,5 \pm 5,9$ & & \\
\hline \multicolumn{2}{|l|}{ Department } & \multirow{5}{*}{12,140} & \multirow{5}{*}{0,001} \\
\hline Basic educational sciences & $29,4 \pm 5,5$ & & \\
\hline Liberal arts & $27,0 \pm 5,5$ & & \\
\hline Science* & $34,3 \pm 8,4$ & & \\
\hline Educational sciences & $27,4 \pm 8,5$ & & \\
\hline \multicolumn{2}{|l|}{ Family type } & \multirow{4}{*}{6,092} & \multirow{4}{*}{0,014} \\
\hline Elementary family & $28,5 \pm 5,8$ & & \\
\hline Extended family & $27,3 \pm 6,0$ & & \\
\hline Parents separated* & $29,5 \pm 7,8$ & & \\
\hline \multicolumn{2}{|l|}{ Mother education level } & \multirow{5}{*}{0,119} & \multirow{5}{*}{0,731} \\
\hline Illiterate & $28,3 \pm 6,0$ & & \\
\hline Literate & $27,2 \pm 6,8$ & & \\
\hline Primary education & $28,1 \pm 5,7$ & & \\
\hline High school and above & $29,5 \pm 6,0$ & & \\
\hline \multicolumn{2}{|l|}{ Father education level } & \multirow{5}{*}{3,490} & \multirow{5}{*}{0,063} \\
\hline Illiterate & $25,5 \pm 6,5$ & & \\
\hline Literate & $26,0 \pm 6,5$ & & \\
\hline Primary education & $27,9 \pm 5,9$ & & \\
\hline High school and above & $29,7 \pm 5,6$ & & \\
\hline $\begin{array}{l}\text { E-health literacy scale total } \\
\text { score }\end{array}$ & $28.4 \pm 0.3$ & & \\
\hline
\end{tabular}

When the total scores of the e-health literacy scale are compared between the departments in which students study The total score average of the students studying in the science department was found to be significantly higher than the students studying in other departments. ( $p$ $<0.005$ ).

Again, when the scale total scores are compared with the family type status of the students, the total score averages of the students whose parents were separated were found to be significantly higher than the other groups. ( $p$ $<0.005)$.

Although the e-health literacy scale total score averages were higher in the 18-24 age group, males, those with social security, those who stated that they had no illness, and those whose mother and father had high school and above education level, there was no significant difference $(p>0.005)$.

The total mean score of the students from the e-health literacy scale was $28.4 \pm 0.3$.

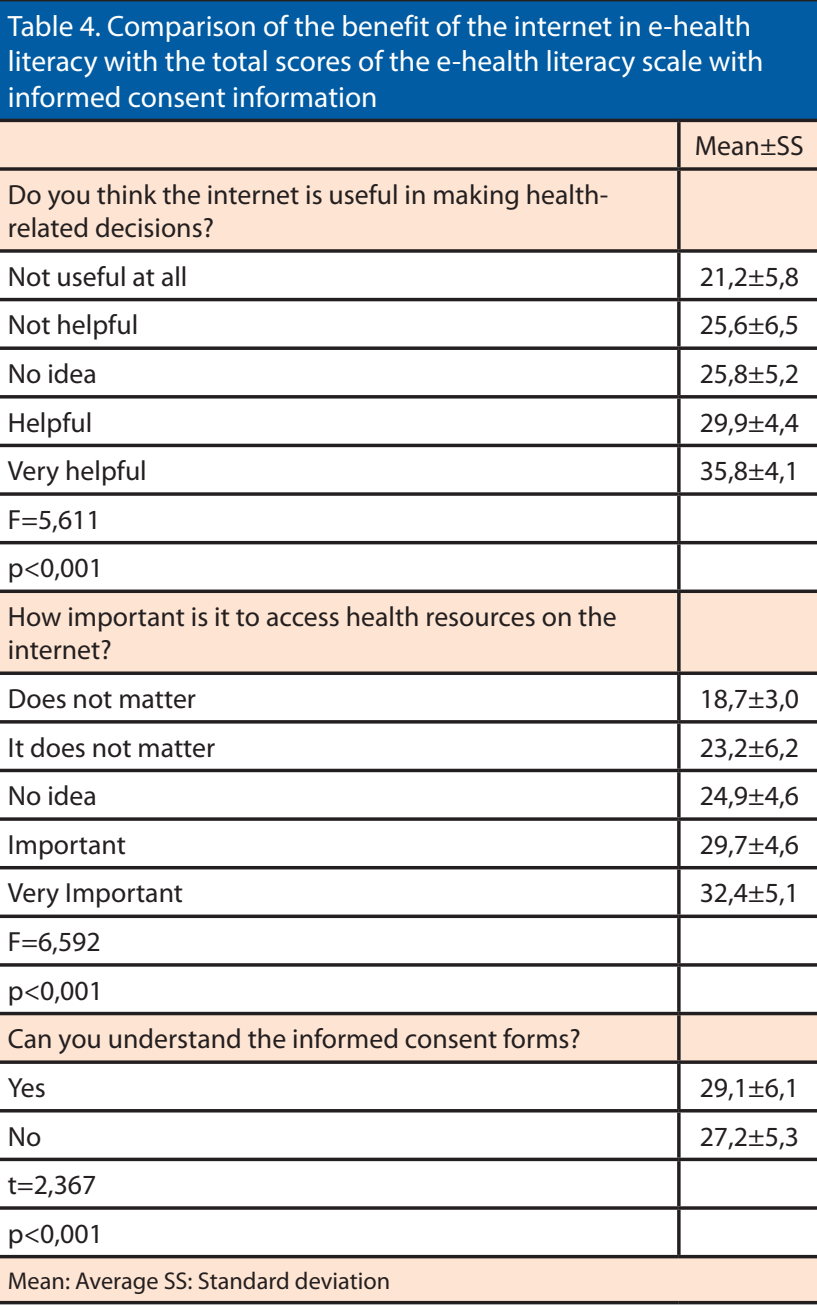

The total score average of the e-health literacy scale was significantly higher than the other groups in the students who stated that the internet was very useful in health-related decisions $(p<0.005)$. 
The total score average of the scale of the students who stated that the Internet plays a very important role in reaching health-related issues was found to be significantly higher than the other groups. ( $p<0.005)$. The scale total score mean of the students who stated that they could understand the informed consent forms was found to be significantly higher than the other groups $(p<0.005)$.

\section{Discussion}

The average age of the study group was $21.0 \pm 0.1$ years, $69.0 \%$ of them were women. $52.3 \%$ were studying in the department of basic educational sciences. $87.4 \%$ of them had social security, $70.6 \%$ of them were living in a student dormitory (Table 1).

In our study, the rate of those who stated that they received support from a physician when they had problems regarding their health-related information and compliance with medical advice or recommendations was high (Table 2). In addition, students stated that the internet was effective in reaching health-related issues and making decisions as a result of this information. (Table 2). This result obtained; Although students express that they receive support from physicians in health-related issues, they think that they see the web environment as an important tool in accessing useful and health-related resources and can refer to internet resources when they feel incomplete.

Approximately one-fifth (21.0\%) of the students in our study had knowledge about e-health literacy, the vast majority $(57.7 \%)$ stated that they could understand the informed consent forms. (Table 2). This result obtained from the study; Although they do not have a problem with informed consents, it suggests that there may be a lack of conceptual knowledge about e-health literacy among students.

In our study, the total score that university students got from the scale was found to be $28.4 \pm 0.3$. (Table3). In our study, it was determined that the e-health literacy scale mean scores of the students were above the middle level.

In the study conducted by Tsukahara et al. (2020) with university students, the students' score on the scale was found to be 23.6. When looking at other studies in the literature, Dashti et al. (2017), in a study they conducted with university students in Iran, the average e-health literacy score of the students was found to be 28.2. Britt et al. (2017) in the study they conducted with 422 undergraduate students in America, the average e-health literacy score of the students was determined as 31.9. Although our study is compatible with the literature, there are studies in which the total score of e-health literacy is higher than our study. It can be thought that this difference may be due to the differences in students' access to information and self-expression.

Şengül et al. (10); It was stated that the use of the Internet, primarily in communication and information exchange, affects e-health literacy levels, students generally have e-health literacy perception and use the Internet at a high rate. Yang et al. (2017) found that university students with higher e-Health literacy participated more in health-promoting activities than those with functional and interactive literacy.

In our study, the total score average of the students studying in the science department was significantly higher than the students studying in other departments (Table $3)$.

Students in this group on health issues They use the internet more to get information and the reason for this may be that they are effective in accessing and interpreting information about health problems.

In our study, the total score average of the students whose parents were separated was significantly higher than the other groups (Table 3). This result may be due to the fact that he is a member of the broken family, unable to reach and consult the parents about their own health decisions, and therefore they see the Internet as more accessible to information..

In our study, the total score average of the students who reported that access to health-related issues using the internet was effective in making decisions based on this was found to be higher. (Table 4).

This result obtained from the answers given to the questions measuring the usefulness of the internet in e-health literacy in our study reveals that the internet access to health-related topics they are curious about is common among students.

In the study of Şengül et al. (10), it was stated by students that the internet is an important resource in making decisions about their health and accessing health resources. 
According to a study conducted with young people aged $15-24$ (11); Internet usage rate is $90.0 \%$, more than twothirds of them get online health information, half of the youth learn about a specific disease such as cancer, and four out of ten of the youth stated that they use the internet to research sexually transmitted diseases and similar issues. In addition, approximately four out of ten people participating in the study reported that the health information they obtained from the internet was "very useful", while one in seven reported that they contacted a healthcare provider after the health information they received.

The students who stated that they could understand the informed consent forms obtained from the scale significantly higher than the other groups. (Table 4).

This result obtained; It is suggested that these skills of young people can be developed in terms of seeking, accessing, understanding and interpreting information from internet resources on health-related issues.

\section{Conclusion}

In this study, which was conducted to determine the e-health literacy levels of students studying at the faculty of education and their attitudes towards internet use and the factors affecting this attitude, it was found that students' use of the Internet in the field of health was above the medium level; It was concluded that when students had problems in compliance with health-related information and medical advice or recommendations, they mostly received support from physicians, as well as they found web tools useful and important in making health-related decisions and accessing resources on health issues. Due to the increase in the use of social media and the accessibility of information and applications in the field of health through the internet, it is possible to conduct studies in wider and different groups, students who use internet tools intensively to access and use correct and reliable resources related to health on the Internet. recommended to be informed.

Limitations of the study: Since the study was conducted in a university, it is not possible to generalize the results obtained to all students.

\section{References}

1. Ergün, S., Sürücüler, H. K., \& Işık, R. (2019). Ergenlerde e-Sağlık Okuryazarlığı ve Sağlıkı Yaşam Biçimi Davranışları: Balıkesir Örneği. JAREN, 5(3), 194-203. DOI: 10.5222/jaren.2019.65002
2. Bertot JC, Jaeger PT, Hansen D. The Impact Of Polices On Government Social Media Usage: Issues, Challenges, And Recommendations. Government Information Quarterly 2012; 29(1):30-40. https://doi.org/10.1016/j.giq.2011.04.004

3. Chretien KC, Kind T. Social media and clinical care ethical, professional, and social implications. Circulation 2013;127(13):14131421. https://doi.org/10.1161/CIRCULATIONAHA.112.128017

4. Babacan M, Haşlak I, Hira I. Sosyal Medya ve Arap Baharı. Akademik Incelemeler Dergisi 2011; 6(2):63-92.

5. Aslantekin, F, Yumrutaş M. Sağlık Okuryazarlığı Ve Ölçümü. TAF Preventive Medicine Bulletin 2014;13(4):327- 334. DOI:10.5455/ pmb1-1364566995

6. Çimen, Z., Bayık Temel A. Kronik Hastalığı Olan Yaşlı Bireylerde Sağlık Okuryazarlığı ve Sağlık Algısı Illişkisi. Ege Üniversitesi, Sağlık Bilimleri Enstitüsü, Halk Sağlığı Hemşireliği, Yayınlanmamış Yüksek Lisans Tezi, İzmir 2015.

7. Pourrazavi, S., Kouzekanani, K., Bazargan-Hejazi, S., Shaghaghi, A., Hashemiparast, M., Fathifar, Z., \& Allahverdipour, H. (2020). Theorybased E-health literacy interventions in older adults: a systematic review. Archives of public health $=$ Archives belges de sante publique, 78, 72. https://doi.org/10.1186/s13690-020-00455-6.

8. Norman $C D$, Skinner HA. eHealth literacy: essential skills for consumer health in a networked world. Journal of Medical Internet Research 2006; 8(4): e27. doi: 10.2196/jmir.8.2.e9

9. Tamer Gencer Z. Norman ve Skınner'ın E-Sağlık Okuryazarlığı Ölçeğinin Kültürel Uyarlaması İçin Geçerlilik ve Güvenilirlik Çalışması. İstanbul Üniversitesi İletişim Fakültesi Dergisi; 2017(52):131-145. https://doi.org/10.17064/iuifd.333165

10. Şengül H, Çınar F, Çapar H, Bulut A, Çakmak C. Sağlık Bilimleri Fakültesi Öğrencilerin E-Sağlık Okuryazarlığı Düzeyleri Ve İnternet Kullanımına Yönelik Tutumları: Bir Vakıf Üniversitesi Örneği. Journal of Social And Humanities Sciences Research 2017; 4(12): 1277-1287. Jshsr.com Journal of Social and Humanities Sciences Research (ISSN:2459-1149)

11. Rideout, Victoria (2001). Generation Rx.Com: How Young People Use the Internet for Health Information. A Kaiser Family Foundation Survey. California,USA.

12. Dashti S, Peyman N, Tajfard M, Esmaeeli H. E-Health literacy of medical and health sciences university students in Mashhad, Iran in 2016: a pilot study. Electronic Physician. 2017 Mar;9(3):3966-3973. DOI: $10.19082 / 3966$

13. Britt R, Collins W, Wilson K, Linnemeier G, Englebert A eHealth Literacy and Health Behaviors Affecting Modern College Students: A Pilot Study of Issues Identified by the American College Health Association J Med Internet Res 2017;19(12):e392 URL: https://www. jmir.org/2017/12/e392 DOI: 10.2196/jmir.3100

14. Tsukahara, S., Yamaguchi, S., Igarashi, F., Uruma, R., Ikuina, N., Iwakura, K., Koizumi, K., \& Sato, Y. (2020). Association of eHealth Literacy With Lifestyle Behaviors in University Students: Questionnaire-Based Cross-Sectional Study. Journal of medical Internet research, 22(6), e18155. https://doi.org/10.2196/18155

15. Yang, S. C., Luo, Y. F., \& Chiang, C. H. (2017). The Associations Among Individual Factors, eHealth Literacy, and Health-Promoting Lifestyles Among College Students. Journal of medical Internet research, 19(1), e15. https://doi.org/10.2196/jmir.5964

16. Hsu, W., Chiang, C., \& Yang, S. (2014). The effect of individual factors on health behaviors among college students: the mediating effects of eHealth literacy. Journal of medical Internet research, 16(12), e287. https://doi.org/10.2196/jmir.3542. 